\title{
PELATIHAN APLIKASI TURNITIN DAN MENDELEY SOFTWARE BAGI MAHASISWA UNNES DALAM RANGKA PENINGKAATAN KOMPETENSI
}

\author{
Dhoni Hartanto', Wara Dyah Pita Rengga ${ }^{2),}$ Zuhriyan Ash Shiddieqy Bahlawan ${ }^{3)}$, \\ Irene Nindita Pradnya ${ }^{4}$, Waliyuddin Sammadikun 5), Akhmad Sutrisno ${ }^{6}$ \\ 1. Department of Chemical Engineering,Universitas Negeri Semarang,Semarang, Indonesia \\ KampusUNNES Sekaran Gunungpati, Semarang 50229, Indonesia
}

\begin{abstract}
ABSTRAK
Di dalam dunia akademik, akademisi tidak pernah lepas dari budaya menulis artikel ilmiah. Baik penulisan artikel untuk mengikuti suatu lomba, memenuhi tugas kuliah, menulis laporan penelitian hingga artikel untuk dipublikasikan pada jurnal baik nasional maupun internasional. Permasalahan utama yang dialami penulis serta mitra dalam menuliskan artikel ilmiah adalah masalah orisinalitas, praktik plagiarisme serta penyusunan refrensi. Plagiarisme merupakan salah satu tindak pidana yang mengambil, menerbitkan atau menyatakan sebagai milik sendiri dari orang lain, dalam hal ini hasil dari suatu pemikiran sang pencipta. Praktik plagiarisme dalam penulisan tugas, karya ilmiah, skripsi maupun disertasi masih banyak kita jumpai di kalangan akademisi, baik mahasiswa, guru maupun dosen. Sebelum kegiatan sosialisasi, dilakukan observasi untuk mengetahui tingkat pengetahuan yang dimiliki oleh para peserta tentang penulisan artikel terutama mengenai plagiasi dan penyusunan refrensi. Metode yang dilakukan adalah tanya jawab. Hampir $90 \%$ peserta belum mengetahui cara menggunakan Turnitin dan Mendeley dalam penulisan jurnal. Hasil kuisioner mahasiswa sangat puas dengan adanya pelatihan Turnitin dan Mendeley.
\end{abstract}

Kata kunci: Turnitin, Mendeley, Plagiasi.

\begin{abstract}
In the academic world, academics have never been separated from the culture of writing scientific articles. Both writing articles to participate in a competition, fulfilling college assignments, writing research reports to articles for publication in national and international journals. The main problems experienced by writers and partners in writing scientific articles are the problems of originality, the practice of plagiarism and the preparation of references. Plagiarism is a criminal offense that takes, publishes or states as one's own property from others, in this case the result of a thought of the creator. Plagiarism practice in writing assignments, scientific work, thesis or dissertation is still widely encountered in academics, both students, teachers and lecturers. Before the socialization activities, observations were made to find out the level of knowledge possessed by the participants about article writing, especially regarding plagiarism and drafting references. The method used is question and answer. Nearly $90 \%$ of participants did not know how to use Turnitin and Mendeley in journal writing. The results of the student questionnaire were very satisfied with the Turnitin and Mendeley training.
\end{abstract}

Kata kunci: Turnitin, Mendeley, Plagiarism

\section{PENDAHULUAN}

Di dalam dunia akademik, akademisi tidak pernah lepas dari budaya menulis artikel ilmiah. Baik penulisan artikel untuk mengikuti suatu lomba, memenuhi tugas kuliah, menulis laporan penelitian hingga artikel untuk dipublikasikan pada jurnal baik nasional maupun internasional. Permasalahan utama yang dialami penulis serta mitra dalam menuliskan artikel ilmiah adalah masalah orisinalitas, praktik plagiarisme serta penyusunan refrensi. 
Plagiarisme merupakan salah satu tindak pidana yang mengambil, menerbitkan atau menyatakan sebagai milik sendiri dari orang lain, dalam hal ini hasil dari suatu pemikiran sang pencipta. (Kurniawati dkk, 2014) Praktik plagiarisme dalam penulisan tugas, karya ilmiah, skripsi maupun disertasi masih banyak kita jumpai di kalangan akademisi, baik mahasiswa, guru maupun dosen. Dalam rangka meminimalisir praktik plagiarism, maka diperlukan pendeteksian terhadap penulisan. Hal ini disebabkan tidaklah cukup hanya mengingatkan kepada mahasiswa, guru serta dosen bahwa tindakan plagiarisme tidak baik untuk dilakukan dalam penulisan sebuah karya. Lalu yang kedua, proses pengecekan dalam bentuk manual juga sangat tidak disarankan untuk dilakukan karena jumlah penulisan yang banyak. Bersumber dari masalah tersebut, maka diperlukan software yang terbaik. Saat ini website Turnitin telah mencapai lebih dari 500 juta submission serta digunakan lebih dari 30 juta mahasiswa pada 15.000 lembaga pendidikan di seluruh dunia (Turnitin.com, 2018)

Dalam penyususnan jenis refrensi yang digunakan tiap jurnal berbedabeda, maka penggunaan jenis refrensi juga berbeda, aplikasi Mendeley menyediakan beberapa jenis refrensi. Sebagai acuan dalam penulisan skripsi maupun artikel ilmiah nantinya.

\section{METODE PELAKSANAAN}

Kegiatan Pengabdian kepada Masyarakat ini akan dilakukan dengan melakukan langkah metodologis yang meliputi identifikasi, pengorganisasian, penyuluhan, pelatihan, program aksi dan evaluasi.

\section{Identifikasi}

Langkah ini diperlukan untuk melakukan pendataan jumlah mahasiswa Teknik Kimia UNNES serta peserta Program Pendidikan Profesi Guru di Teknik Kimia UNNES yang memiliki potensi untuk mempelajari Turnitin sabagai perangkat lunak pengelola originality dan similiarity.

\section{Pengorganisasian}

Langkah ini meliputi negosiasi dengan pihak-pihak terkait, pengurusan ijin, penetapan waktu, tempat, pembiayaan, peserta, materi dan peralatan yang berkaitan dengan program pengabdian kepada masyarakat ini.

\section{Program Aksi}

Adalah kegiatan pemberian pelatihan perangkat lunak Turnitin sebagai dasar penulisan artikel ilmiah diamana peserta pelatihan dan tim pengabdian masyarakat terlibat secara langsung dalam kegiatan ini.

\section{Evaluasi}

Evaluasi dilakukan terhadap keseluruhan pelaksanaan program. Pada kegiatan ini juga akan dievaluasi kelebihan dan kekurangan, serta mempertimbangkan masukanmasukan dari peserta pelatihan yang bersifat konstruktif.

Untuk mengetahui tingkat keberhasilan kegiatan pengabdian kepada masyarakat evaluasi akan dilakukan terhadap pelaksanaan pelatihan. Evaluasi ini sangat penting karena tujuan program ini adalah untuk meningkatkan pemahaman dan pengetahuan mahasiswa dalam menggunakan peangkat lunak 
Turnitin sebagai media pelelolaan sumber pustaka. Keberhasilan pelatihan dan praktek dievaluasi dengan penyebaran angket kepada peserta yang berisi tentang sikap atau tanggapan mengenai manfaat penggunaan Turnitin dalam penulisan artikel ilmiah.

Diantara kriteria dari bentuk tes evaluasi yang akan diungkap adalah:

\section{Kemudahan penggunaan Turnitin dalam mengelola plagiarisme.}

2. Kemudahan Turnitin sebagai media sosial untuk dapat berinteraksi dengan sesame pengguna Turnitin.

3. Kemudahan Turnitin dalam mengecek originality dan similiarity dengan karya ilmiah orang lain.

Kegiatan dikatakan berhasil apabila masyarakat sasaran telah memenuhi minimal dua kriteria:

1. Dapat memahami dan menggunakan fitur - fitur yang disediakan oleh Turnity dengan baik.

2. Dapat berinteraksi bersama dengan kelompok penelitian dalam berbagi informasi artikel ilmiah terkini.

\section{HASIL \\ PEMBAHASAN}

DAN

\section{Minat Peserta Terhadap Pelatihan}

Dari kuisioner yang diberikan kepada peserta 3 bagian pertanyaan terhadap 34 responden yang masing masing terdapat 5-6 pertanyaan yang berkaitan dengan identifikasi peserta, materi pelatihan turnitin dan mendeley dan fasilitas pelatihan yang telah dilaksanakan dengan nilai $1=$ sangat kurang, 2=kurang, $3=$ cukup, 4=baik dan 5 sangat baik.
Data yang telah diolah ditampilkan pada gambar 1. Merupakan indeks minat dari peserta terhadap pelatihan Turnitin dan Mendeley.

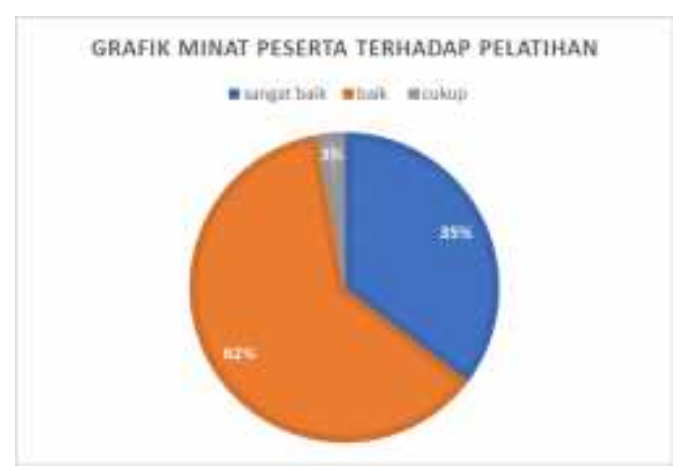

Gambar 1. Presentase Minat Peserta Pelatihan.

Dari data peminatan mahasiswa didapat nilai koefisien korelasi sebesar 0.6482 yang menandakan bahwa data tersebut memiliki nilai koefisien korelasi yang tinggi. Selain itu minat peserta pelatihan $35 \%$ sangat baik, $65 \%$ baik dan $3 \%$ cukup. Rata-rata peserta memiliki minat yang cukup baik terhadap pelatihan Turnitin dan Mendeley sebesar 65\%.

\section{Kepuasan Peserta Terhadap Materi yang Diberikan}

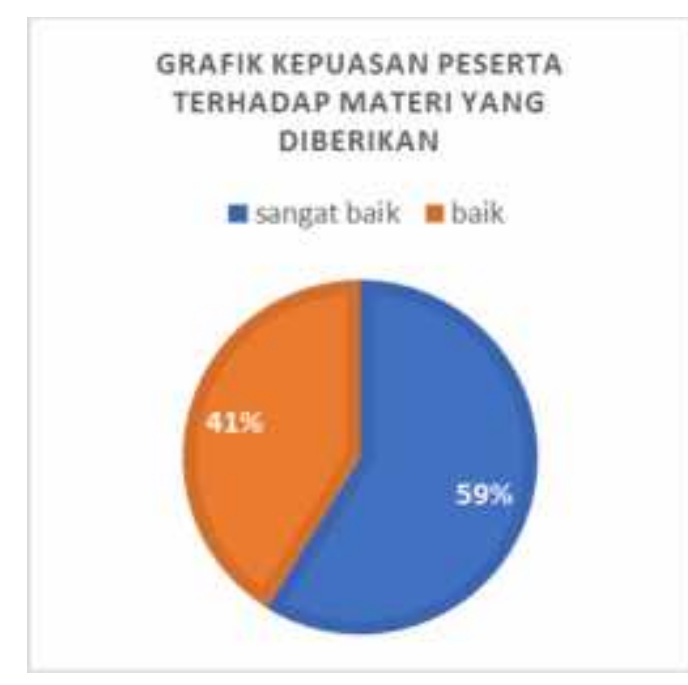

Gambar 2. Presentase Kepuasan Peserta Terhadap Materi yang Diberikan. 
Dari Gambar.2 Terlihat bahwa peserta pelatihan merespon sangat baik terhadap kepuasan materi yang diberikan dengan nilai sangat baik (indeks 5) sebesar 59\% dan nilai baik (indeks 4) sebesar $41 \%$ data kepuasan peserta terhadap materi yang diberikan memilili nilai koefisien korelasi sebesar 0.5782 yang menandakan bahwa data tersebut memiliki validitas yang cukup baik. Dari presentase tersebut menunjukkan bahwa materi yang diberikan tkepada peserta dapat difahami dengan sangat baik.

\section{Kepuasan Peserta Terhadap Fasilitas Yang Diberikan}

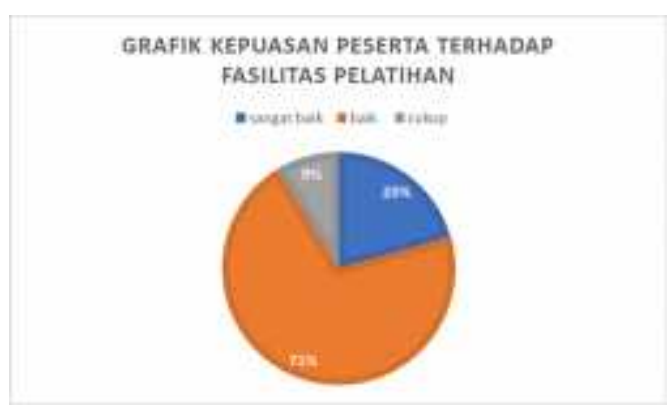

Gambar 3. Presentase Kepuasan Peserta Terhadap Fasilitas yang Diberikan.

Dari Gambar 3 Terlihat bahwa kepuasan peserta dengan nilai sangat baik (indeks 5) sebesar 20\%, sedangkan kepuasan dengan nilai baik (indeks 4) sebesar $71 \%$ dan kepuasan dengan nilai cukup (indeks 3) sebesar 9\%. Nilai kepuasan fasilitas mempunyai nilai 0,742 yang menandakan bahwa data tersebut cukup valid. Nilai kepuasan peserta terhadap faasilitas lebih rendah terhadap grafik kepuasan terhadap materi, hal ini disebabkan karena panitia tidak menyediakan laptop sehingga peserta harus membawa laptop sendiri, dan jaringan internet yang kurang bagus.

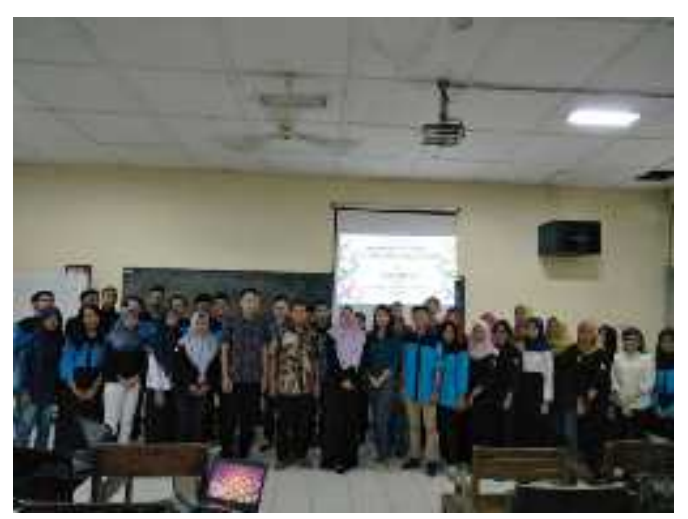

Gambar 4. Dokumentasi Acara

\section{KESIMPULAN}

Pelatihan tersebut berjalan lancar dengan penilaian minat peserta yang sangat tinggi, serta materi yang diberikan juga mendapat apresisasi yang cukup baik, tetapi fasilitas yang disediakan dari panitia terbatas karena minimnya laptop/ komputer serta koneksi internet yang tidak stabil.

\section{REFERENSI}

iParadigms. 2004. iParadigms: Digital solutions for a new era in information, available at: http://www.iparadigms.com (accessed at March $13^{\text {th }}, 2018$ )

Kurniawati, Ana, Wulandari, Lily and Wicaksana, I Wayan Simri. 2014. Perbandingan Tools Deteksi Plagiarisme untuk Dokumen. Skripsi Program Studi Sistem Informasi. Universitas Gunadarma Library, p. 523-526.

Turnitin Company. 2018. http://www.turnitin.com/en_us/a bout-us/our-company, (accessed at March $13^{\text {th }}, 2018$ ) (accessed at March $13^{\text {th }}, 2018$ ) 